\title{
Perancangan Perangkat Lunak Diagnostik untuk Analisis Ligamen Bahu dengan Pencitraan Ultrasonik
}

Design of Diagnostic Software for Shoulder Ligament Analysis by Ultrasound Imaging

Norma Hermawan $^{1}$, Mizuki Fujiwara ${ }^{2}$, Yoshihiro Hagiwara ${ }^{3}$, Yoshifumi Saijo ${ }^{4}$

${ }^{1}$ Departemen Teknik Biomedik, Institut Teknologi Sepuluh Nopember

${ }^{2,4}$ Graduate School of Biomedical Engineering, Tohoku University

${ }^{3}$ Graduate School of Medicine, Tohoku University

E-mail: ${ }^{1}$ norma.hermawan@bme.its.ac.id, ${ }^{2}$ mizuki.fuji.k@gmail.com, ${ }^{3}$ hagi@med.tohoku.ac.jp,

${ }^{4}$ saijo@tohoku.ac.jp

\begin{abstract}
Abstrak
Makalah ini menjelaskan implementasi perangkat lunak dengan antar muka pengguna grafis (GUI) untuk menganalisis citra bergerak ultrasonik dari ligament bahu. Perangkat lunak yang dirancang dapat bermanfaat di bidang medis khususnya sebagai alat bantu identifikasi penyakit yang berhubungan dengan kelainan gerak dan nyeri pada bahu. Pada prinsipnya, perangkat lunak yang dirancang bekerja dengan cara memvisualisasikan lapisan jaringan di bahu berdasarkan kecepatannya selama gerakan melalui metode speckle tracking citra B-mode ultrasonik. Ligamen dalam bahu yang mengalami pelekatan dapat diamati dan diukur secara kuantitatif dalam besaran indeks dengan cara tersebut. Indeks tersebut dihitung dari perbedaan kecepatan antara otot subscapularis dan otot deltoid bahu. Hasil pengamatan menunjukkan bahwa pasien dengan restriksi gerakan pada bahu mengalami pelekatan subscapularis yang ditunjukkan oleh nilai Indeks Adhesi (IA) yang tinggi. Hal ini menunjukkan bahwa keterbatasan gerak bahu dapat dikuantisasi dengan besaran indeks. Kelebihan dari penggunaan perangkat lunak analisis citra ultrasonik sebagai alat bantu diagnosis adalah sifatnya yang non-invasif dan semua data pengukuran dapat diambil dengan menggunakan mesin ultrasonografi konvensional.
\end{abstract}

Kata kunci: speckle tracking, alat bantu diagnosis, citra ultrasonik, adhesive capsulitis

\begin{abstract}
This paper describes an implementation of a software with Graphical User Interface (GUI) for analyzing ultrasound movie of shoulder ligament. The designed software could be beneficial especially in medical field as a supporting tool to identify shoulder pain and movement abnormality related disease. In principle, the designed software works by visualizing layers of tissue in the shoulder based on their velocity during a movement by speckle tracking method of ultrasound B-mode images. By this method, the shoulder ligament with adhesion each other could be observed and quantitatively measured in index. The index is calculated from the velocity difference between subscapularis and the deltoid muscle of the shoulder. The observation shows that patient with restricted shoulder motion encounter a subscapularis adhesion which is identified from high adhesion index. The result suggested that motion restriction of the shoulder can be quantized by index measure. The merit of ultrasound image analyzing software implementation as a diagnosis support tool is its non-invasiveness and its ability to use the available data that can be obtained by a conventional ultrasound machine.
\end{abstract}

Keywords: speckle tracking, diagnostic tool, ultrasound image, adhesive capsulitis 


\section{PENDAHULUAN}

Bahu beku yang dalam bahasa inggris dikenal sebagai frozen shoulder atau Adhesive Capsulitis (AC) adalah penyakit yang secara klinis ditandai dengan nyeri, kekakuan, dan hilangnya rentang gerak bahu. Dalam survei acak terhadap 9.696 orang dewasa usia kerja, AC telah mempengaruhi $8,2 \%$ di antara pria dan $10,1 \%$ di antara wanita dari populasi [1]. Etiologi AC tidak sepenuhnya dipahami. Namun, perkembangannya dapat diperlambat dan bahkan dihentikan jika tingkat keparahannya dapat dideteksi secara akurat dan diberikan terapi yang sesuai [2]. Sinar-X dari AC biasanya digunakan untuk menyingkirkan penyebab lain seperti artritis glenohumeral. Magnetic Resonance Imaging (MRI) dapat menunjukkan sedikit penebalan pada kapsul sendi dan ligamen coracohumeral (CHL) serta membantu mengidentifikasi robekan rotator cuff [3]. Sonografi sering dikecualikan dalam diagnosis AC karena kurangnya kriteria diagnostik yang spesifik. Namun, penelitian sebelumnya telah menunjukkan prospek pemanfaatan sonografi untuk diagnosis AC dengan memvisualisasikan CHL yang menebal dan mengakses parameter dinamis pada pasien [4].

Analisis abnormalitas dari jaringan tubuh manusia menggunakan metode ultrasonik telah dilakukan sejak lama dengan metode turunan Doppler. Permasalahan dengan metode Doppler dalam analisis dinamis adalah kebutuhan presisi peletakan transducer dengan sudut kemiringan yang harus dijaga seminimal mungkin. Keterbatasan dimensi ini berakibat menurunkan reproduktifitas pengukuran pada studi dan pengamatan. Akibatnya, menganalisis deformasi atau kecepatan jaringan akan menjadi rumit dan memakan waktu. Sebaliknya, analisis dua dimensi akan mengungkapkan lebih banyak informasi dan menyelesaikan masalah ketergantungan sudut. Berbagai metode telah dikembangkan seperti multiple-beam Doppler [5], pelacakan spekel [6], dan modulasi spasial bidang suara [7]. Kemajuan ultrasonografi modern membawa metode tersebut menjadi layak untuk penelitian praktis dan implementasi komersial. Pada level molekuler, penggunaan teknologi pencitraan ultrasonik dapat bermanfaat untuk mengidentifikasi karakteristik mekanik dari sel [8].

Speckle tracking merupakan salah satu metode untuk menganalisis karakter jaringan dengan melacak gerakan titik-titik citra $B$-mode ultrasonik dalam sebuah gerakan. Dalam metode speckle tracking, distribusi spasial nilai abu-abu yang disebut pola speckle mengikuti pola jaringan biologis yang mendasarinya, seperti ligamen. Posisi pola unik ini dapat bergerak mengikuti gerakan jaringan. Prinsip dasar metode speckle tracking adalah melacak pola ini selama pergerakan jaringan dalam citra 2-D.

Teknik speckle tracking dapat dipisahkan ke dalam dua kelompok, yaitu block matching dan pendekatan optical flow. Dalam pendekatan block matching, kecocokan terbaik dari suatu kotak pada sebuah frame citra dicari dalam Region of Interest (ROI) pada frame berikutnya. Gerak speckle ditentukan berdasarkan kesamaan maksimum pada proses pencocokan. Peta vektor kecepatan dihasilkan setelah menyelesaikan pencarian pada ROI yang ditetapkan.

Sebagai pendekatan alternatif, metode optical flow menggunakan prinsip kekekalan nilai grayscale yang mengasumsikan bahwa nilai grayscale pada sebuah posisi adalah konstan dari waktu ke waktu. Dalam hal ini, pergerakan nilai grayscale diestimasi berdasarkan perubahan nilai grayscale terhadap waktu dan koordinat spasial. Vektor kecepatan tidak dapat diperkirakan dari prinsip ini saja karena parameter yang tersedia kurang dari yang dibutuhkan untuk menyelesaikan persamaan brightess constancy yang juga dikenal sebagai permasalahan aperture. Untuk mengatasi itu, parameter tambahan seperti kehalusan spasial dan kesamaan lokal diperkenalkan yang menghasilkan banyak turunan teknik optical flow seperti algoritma Horn Schunck [9] dan algoritma Lucas-Kanade [10].

Pada makalah ini, implementasi teknis dari algoritma speckle tracking dijelaskan. Speckle tracking dengan teknik block match dinilai lebih cocok dengan citra B-mode ultrasonik yang memiliki Signal to Noise Ratio (SNR) rendah. Di sisi lain, penerapan metode optical flow lebih terbatas untuk citra bergerak dengan interval frame kecil dan hasil pencitraan berkualitas tinggi seperti Magnetic Resonance Imaging (MRI). Diskusi lebih lanjut tentang implementasi klinis pelacakan bintik untuk mengakses gerakan bahu secara kuantitatif akan dibahas di bagian 
eksperimen. Metode ini digunakan untuk memecahkan permasalahan diagnosis AC dengan menggunakan ultrasonografi dinamis, dengan menampilkan nilai kuantitatif dari parameter pelekatan ligamen pada bahu.

\section{METODE PENELITIAN}

Secara umum, penelitian ini merealisasikan implementasi dari algoritma speckle tracking menjadi sebuah perangkat lunak dengan tampilan grafis, dan dibantu dengan program pre-compiled untuk meningkatkan kecepatan eksekusi dari proses analisis.

\subsection{Metode Speckle Tracking}

Pada dasarnya, pencitraan ultrasonik adalah rekonstruksi gema yang dipantulkan dari pulsa ultrasonik. Ketika sinyal ultrasonik merambat di dalam jaringan, sinyal tersebut dapat menabrak reflektor atau penghambur. Reflektor adalah lokasi di dalam jaringan di mana gelombang ultrasonik dipantulkan kembali ke arah sumber. Pantulan ini terbentuk oleh transisi jaringan dengan impedansi akustik yang berbeda. Di sisi lain, penghambur membiaskan gelombang ultrasonik ke segala arah. Akibatnya, sinyal yang dipantulkan ke transduser cenderung tampak lemah. Proses ini dapat terbentuk dari massa dengan kepadatan berbeda tetapi lebih kecil dari panjang gelombang. Lokasi penghambur menyebar di jaringan, oleh karena itu sinyal yang terdeteksi oleh transduser ultrasonik biasanya merupakan superposisi refleksi oleh beberapa penghambur. Perbedaan waktu antara sinyal membuat interferensi konstruktif atau destruktif pada sinyal yang dipantulkan. Superposisi konstruktif akan memiliki amplitudo lebih besar, sedangkan interferensi destruktif akan terlihat lebih kecil. Pemrosesan dari sinyal frekuensi radio (RF) transducer menghasilkan pola terang dan gelap pada citra. Distribusi spasial dari pola gelap dan terang ini merupakan interferensi konstruktif dan destruktif karena beberapa penghambur dalam jaringan. Distribusi spasial dari pola gelap dan terang ini umumnya didefinisikan sebagai speckle.

Jika penghambur bergerak sepanjang garis rambatan ultrasonik, waktu tempuh refleksi akan meningkat. Namun, posisi masing masing bintik dalam lingkup kecil tidak berubah, sehingga pola interferensi nampak dipertahankan. Di sisi lain, ketika penghambur bergerak tegak lurus terhadap garis balok, pola speckle tertentu bergerak menjauh. Namun, ketika transduser 2 dimensi digunakan, pola speckle dideteksi oleh transducer lain dalam array, dengan syarat gerakan jaringan lebih lambat daripada gerak rambat dari sinyal ultrasonik. Kecepatan bunyi $1530 \mathrm{~m} / \mathrm{s}$ berarti bahwa gerak jaringan dalam orde $\mathrm{cm} / \mathrm{s}$ sekitar 10.000 kali lebih lambat, yang memenuhi syarat tersebut. Idealnya, pelacakan speckle harus dilakukan dengan citra berframe rate tinggi dan berkualitas tinggi untuk secara akurat memvisualisasikan gerakan penghambur dan menghindari artefak citra [11].

\subsection{Algoritma Block Matching}

Salah satu kategori dalam speckle tracking adalah algoritma block matching. Dalam algoritma ini, blok persegi yang disebut kernel dalam sebuah frame dibandingkan dengan area dengan ukuran yang sama dari frame sebelumnya. Area tersebut digeser ke berbagai posisi dan prosedur ini dilakukan berulang kali pada area pencarian yang telah ditentukan. Pergeseran yang menghasilkan kemiripan maksimum dipilih sebagai vektor gerak terbaik untuk kernel tersebut. Beberapa ukuran kesamaan dapat didefinisikan seperti jumlah selisih mutlak atau Sum of Absolute Difference (SAD), selisih rata-rata mutlak (MAD), selisih rata-rata kuadrat (MSD), dan korelasi silang ternormalisasi (NCC). Perhitungan vektor dilakukan secara berulang untuk semua piksel dalam suatu region of interest (ROI) untuk mendapatkan bidang vektor kecepatan. Bidang vektor kecepatan dinamis diperoleh dengan mengulangi pengukuran ini ke semua frame dari urutan citra ultrasonik.

Salah satu metode untuk menentukan kemiripan antara dua blok citra adalah dengan korelasi silang ternormalisasi (NCC). Korelasi adalah operasi matematika yang mirip dengan konvolusi yang diberikan oleh persamaan 1. Korelasi silang digunakan ketika operasi tersebut dilakukan antara sinyal dengan template. Operasi korelasi sinyal dengan dirinya sendiri disebut 
dengan autokorelasi. Biasanya, korelasi digunakan untuk mencari pola singkat atau fitur dari sinyal yang lebih panjang. Ketika metode korelasi silang dilakukan dalam bidang dua dimensi, maka fitur 2 dimensi tersebut dapat dicari di suatu area.

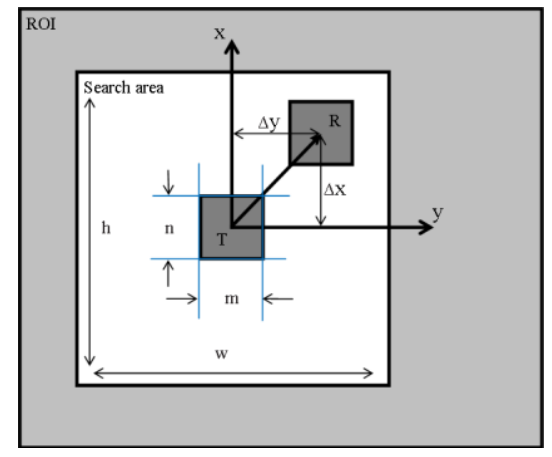

Gambar 1 Algoritma speckle tracking dengan block matching

Output dari korelasi silang akan mencapai puncaknya di lokasi di mana pola citra cocok dengan kernel. Korelasi silang yang dinormalisasi akan menghasilkan nilai perhitungan di antara nilai -1 hingga 1, di mana 0 berarti tidak ada korelasi sama sekali.

$$
[f(t) * g(t)](t)=[\overline{f(-t)} * g(t)](t)
$$

Berbeda dengan korelasi silang, metode $S A D$ membutuhkan sumber daya komputasi yang lebih sedikit karena hanya melibatkan operasi differensial, bukan perkalian. Metode ini mengukur kesamaan antara blok citra dengan membandingkan intensitas piksel-per-piksel dalam suatu kernel. Perbandingan dilakukan dengan mengurangkan setiap nilai piksel dalam sebuah kernel dengan piksel pada area terkait dan menjumlahkan hasil perhitungan untuk semua piksel.

Dengan mengacu pada ilustrasi pencocokan blok SAD pada Gambar 1, nilai minimum SAD di seluruh area pencarian menentukan perpindahan optikal dan vektor kecepatan antar frame. Dalam SAD, persamaan 2 disebut cost function. Dalam perhitungan ini, $\mathrm{w} \times \mathrm{h}$ adalah dimensi dari jendela pencarian, dan $\mathrm{m} \times \mathrm{n}$ adalah dimensi dari kernel.

$$
\begin{gathered}
S A D(\Delta x, \Delta y)=\sum_{i=0}^{m-1} \sum_{j=0}^{n-1}\left|T_{i, j}-R_{i+\Delta x, j+\Delta y}\right| \\
U=\min _{(\Delta x, \Delta y)}\{S A D(\Delta x, \Delta y)\} \\
v=\left.r(\Delta x, \Delta y)^{T}\right|_{U}
\end{gathered}
$$

Dalam perhitungan ini, untuk kernel berukuran $\mathrm{m} \times \mathrm{n}$ dan jendela pencarian berukuran $\mathrm{w} \times \mathrm{h}$, terdapat $(\mathrm{w}-\mathrm{m}+1) \times(\mathrm{h}-\mathrm{n}+1)$ kemungkinan vektor. Jika semua nilai ini dihitung dan kecocokan terbaik ditentukan dari seluruh area pencarian, maka metode ini akan masuk ke dalam kategori yang disebut dengan algoritma full search block matching. Algoritma pencarian dalam metode block matching pada prinsipnya mencari cara untuk menentukan kesamaan maksimum berikutnya tanpa menghitung cost function ke seluruh area pencarian, karena meskipun rasio signal-to-noise dari full search block matching adalah yang tertinggi, metode ini secara komputasi paling mahal di antara algoritma pencarian lainnya. Kebutuhan komputasi meningkat secara proporsional dengan ukuran jendela pencarian. Sebaliknya, algoritma pencarian berbasis step search bekerja dengan mencari kesamaan maksimum tanpa mencoba semua kemungkinan, yang pada gilirannya mengurangi kebutuhan komputasi secara signifikan. 
Tujuan dari algoritma pencarian adalah untuk mendapatkan strategi pencarian yang paling efisien dengan tetap menjaga akurasi deteksi gerakan.

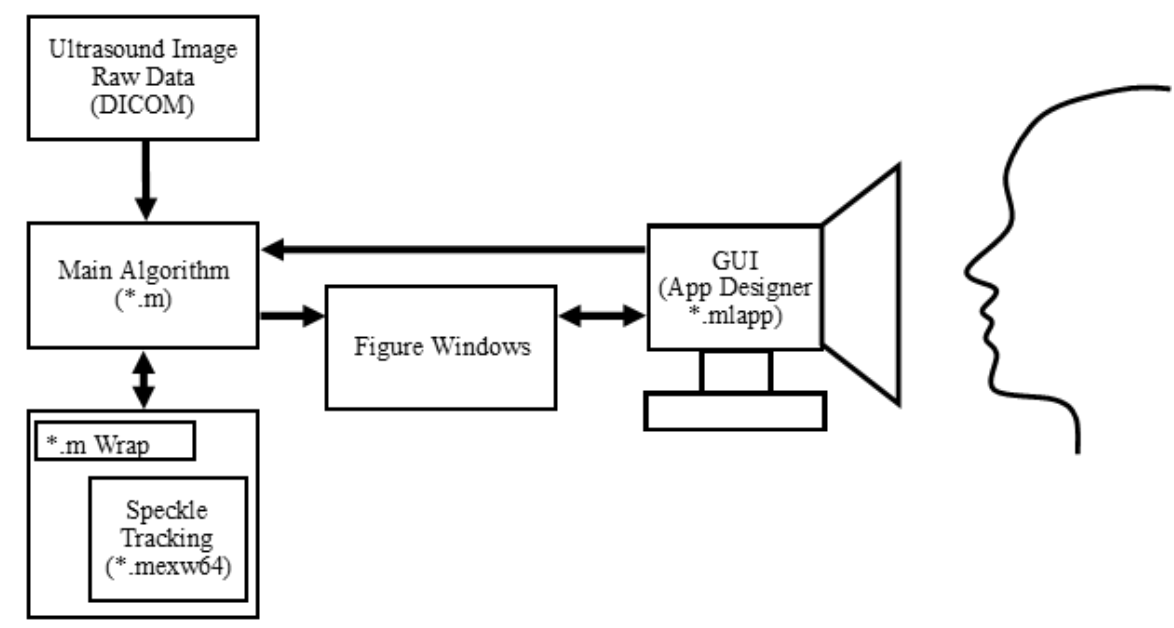

Gambar 2 Implementasi perangkat lunak analisis adhesi ligament

\subsection{Implementasi Perangkat Lunak}

Perangkat lunak untuk pengolahan sinyal berdasarkan speckle tracking ultrasonik untuk visualisasi kecepatan ligamen bahu telah diimplementasikan. Dalam implementasi ini, ROI dipilih dari rangkaian frame citra ultrasonik dalam file berformat DICOM. Perpindahan kernel antar-frame diestimasi dengan algoritma pencocokan blok berbasis SAD. Metode SAD dipilih karena lebih cocok dengan sumber citra ultrasonik yang memiliki SNR rendah. Ukuran kernel dan area pencarian diatur secara eksperimental sesuai dengan data pengukuran.

Algoritma diimplementasikan dalam $\operatorname{MATLAB}^{\circledR}$ (R2019a) dan antarmuka pengguna grafis (GUI) App Designer ${ }^{\mathrm{TM}}$. Untuk mendapatkan komputasi yang lebih cepat, algoritma SAD yang paling membutuhkan sumber daya diimplementasikan dalam fungsi MEX yang telah dikompilasi dan ditulis dalam C. Perangkat lunak disesuaikan dengan sampel data yang tersedia. Namun demikian, fitur penyesuaian parameter diberikan di GUI untuk memungkinkan eksperimen dilakukan terpisah oleh pengguna yang berbeda. Aplikasi MATLAB ${ }^{\circledR}$ telah lazim digunakan dalam implementasi perhitungan matrix [12] atau pengolahan citra digital seperti Face Recognation.[13]

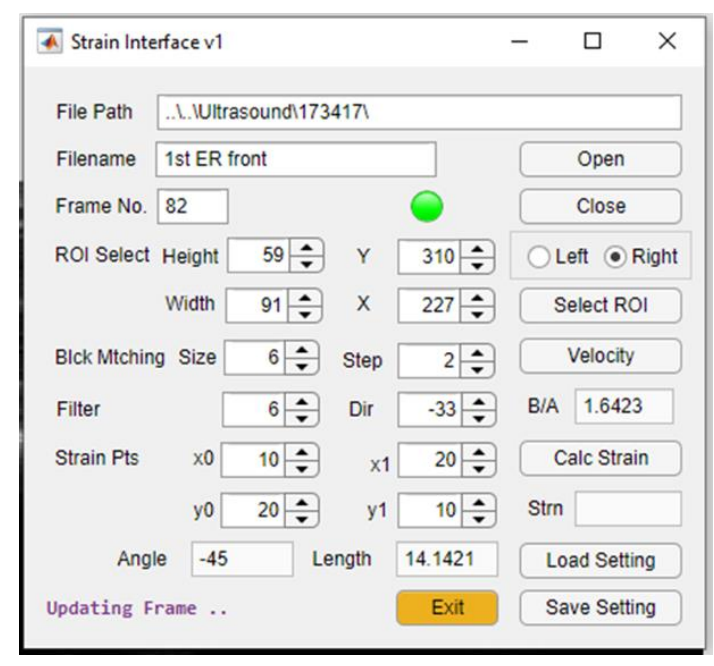

Gambar 3 Panel kontrol antarmuka pengguna grafis (GUI) dari perangkat lunak yang dirancang 


\subsection{Metode Pengujian}

Perangkat lunak yang telah dirancang kemudian digunakan untuk mengukur Indeks Adhesi (IA) ligamen bahu pada pasien dengan keluhan kaku dan nyeri bahu, dan membandingkannya dengan data dari subjek sehat sebagai kontrol. Dalam penelitian ini, total 26 subjek telah disertakan, dengan 22 diantaranya adalah pasien dengan penyakit kaku dan nyeri bahu. 12 dari pasien ini diklasifikasikan lebih lanjut ke dalam kelompok AC sekunder karena terdapat Rotator Cuff Tears (RCT), dan 10 lainnya diklasifikasikan sebagai AC idiopatik. Sisanya adalah 4 peserta subjek normal.

Semua peserta menjalani prosedur sonografi B-mode menggunakan Aplio i800 TUSAI800 (Canon Medical Systems Inc.). Data pengukuran dianalisis dengan metode speckle tracking dengan program tertulis MATLAB ${ }^{\circledR}$.

Prosedur pengukuran dilakukan secara terstandar untuk seluruh subjek, yaitu:

1. Dalam posisi duduk, lengan subjek digerakkan dari posisi netral menuju rotasi internal $45^{\circ}$.

2. Gerakan B-mode direkam dalam visual terbaik dari proses coracoid, otot CHL dan subscapularis (SSC).

3. Rekaman diputar dan dianalisis secara manual untuk menentukan nomor frame di awal dan akhir gerakan.

4. IA dianalisis untuk bagian tengah gerakan dan \pm 3 frame (total 7 frame).

5. Segitiga lemak subcoracoid digunakan sebagai penanda, di mana sudut kiri bawah ROI harus tumpang tindih dengan ujungnya. IA subscapularis dan otot deltoid diukur dengan cara ini.

6. Rentang External Rotation pertama ( $1^{\text {st }}$ ER) maksimum diukur secara terpisah dengan goniometer.

Karena penentuan ROI, awal dan akhir dari citra bergerak dilakukan secara manual, maka reproduktifitas pengukuran diuji dengan mengulangi prosedur dari langkah ke-tiga.

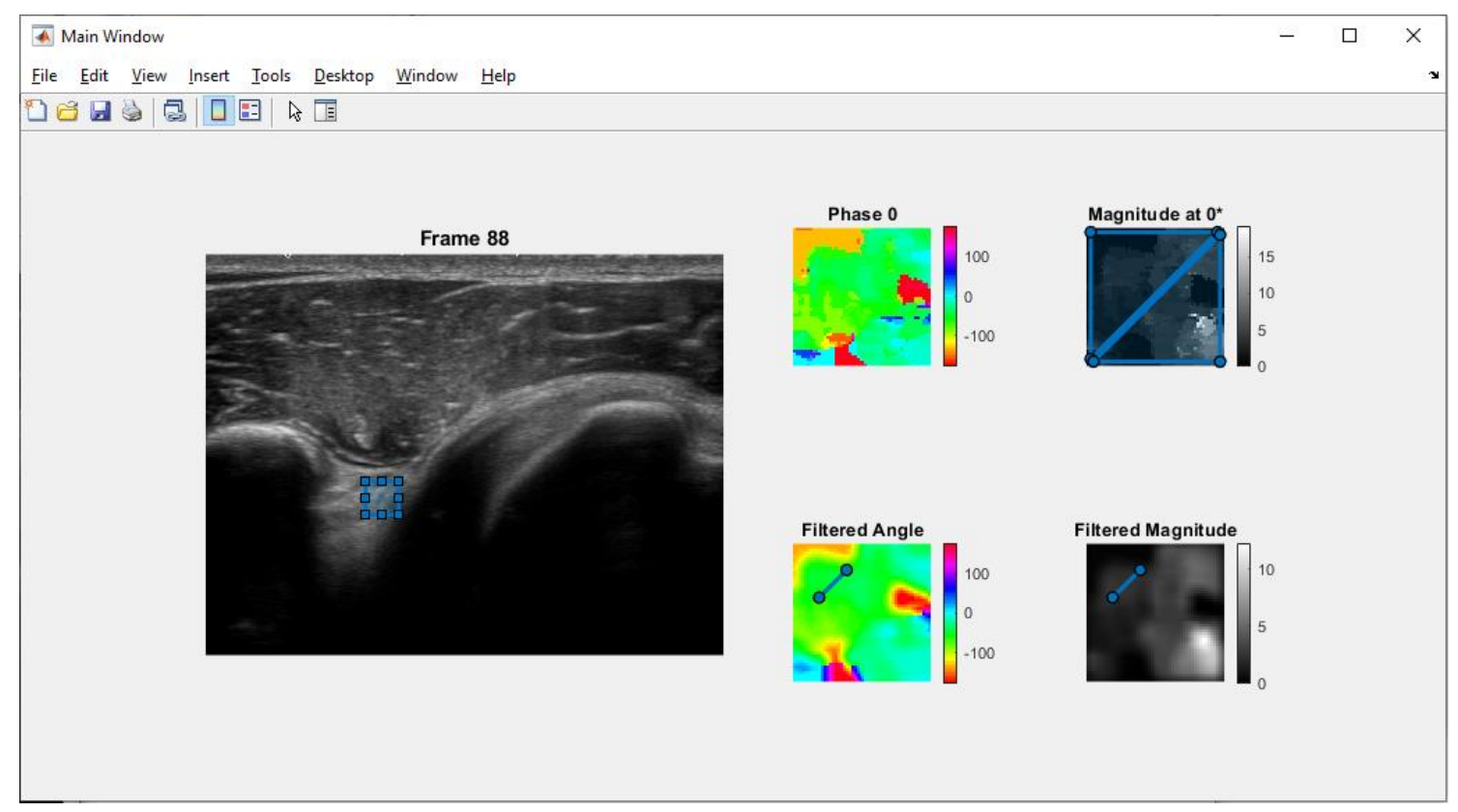

Gambar 4 Tampilan hasil analisis dari perangkat lunak yang dirancang

\section{HASIL DAN PEMBAHASAN}

Gambar 5 menunjukkan analisis kecepatan otot subscapularis dan deltoid dalam ROI berbentuk persegi panjang pada bahu yang sehat. Kecepatan jaringan diwakili oleh panah yang menunjuk ke arah gerak dengan panjang panah sebanding dengan besaran kecepatan. Gerakan dilakukan dari $45^{\circ}$ Internal Rotation (IR) ke posisi netral. Analisis dilakukan pada pertengahan 
frame gerak dengan tambahan 3 frame sebelum dan sesudahnya. IA dihitung sebagai pembagian kecepatan otot deltoid dengan kecepatan subscapularis sesuai ke arah gerakan. Dalam hal ini, IA dari contoh normal selama frame tengah gerakan adalah 0,17 dan nilai IA \pm 3 frame di sekitar tengah diamati di bawah 0,2 . Nilai ini pada dasarnya diartikan sebagai gerakan meluncur bebas subscapularis di bawah otot deltoid. Dalam keadaan ini, subscapularis dapat divisualisasikan, dan kecepatannya dapat dengan mudah dilihat selama pergerakan.



Gambar 5 Vektor kecepatan pada subjek normal

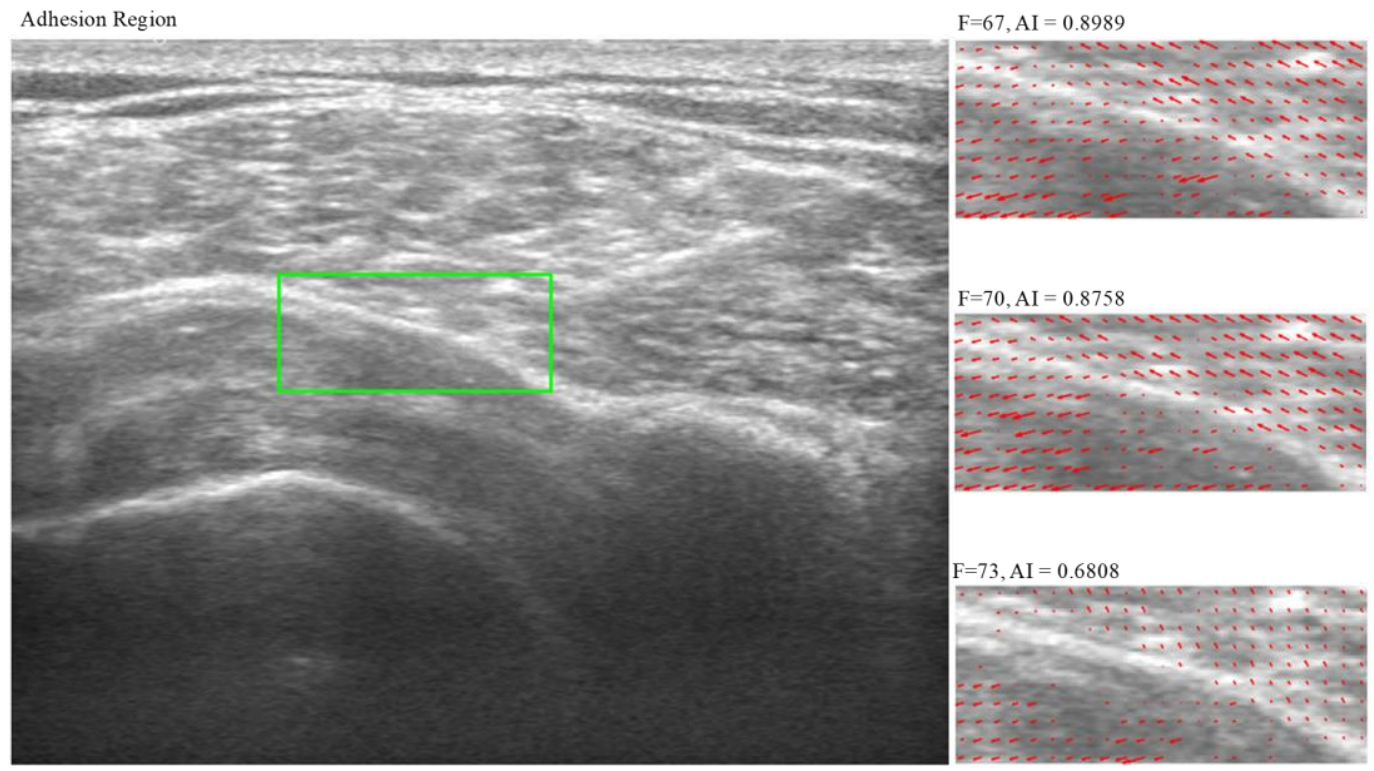

Gambar 6 Vektor kecepatan pada pasien dengan kaku dan nyeri bahu 


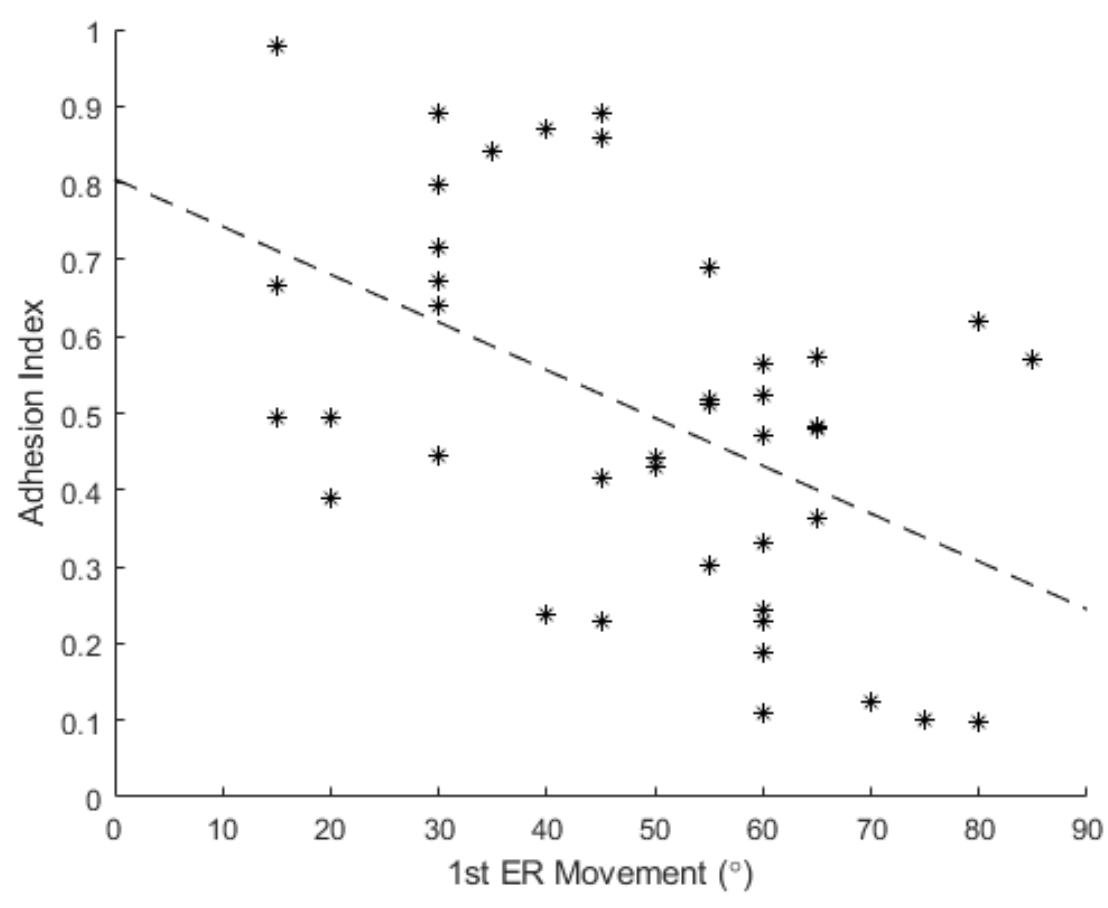

Gambar 7 Hubungan antara Indeks Adhesi (IA) dan ROM

Analisis pelekatan ligamen dengan visualisasi kecepatan speckle tracking bahu peserta dengan diagnosis AC ditunjukkan pada Gambar 6. Pola aliran kecepatan sesaat dianalisis dengan speckle tracking dari citra B-mode ultrasonik. Pada pengamatan ini, IA pada pertengahan frame mendekati nilai satu. Hal ini berarti otot deltoid bergerak dengan kecepatan yang hampir sama dengan subscapularis. Nilai IA dari frame-frame di sekitar pertengahan teramati lebih besar dari 0,6 untuk mayoritas data.

Hubungan antara rentang gerakan atau Range of Motion (ROM) bahu dan IA dari semua subjek ditunjukkan oleh garis regresi pada Gambar 7. dimana IA berkorelasi negatif terhadap ROM dengan koefisien korelasi $\mathrm{R}=-0,489285$. Nyeri dan kekakuan bahu dapat diklasifikasikan lebih lanjut berdasarkan kondisi pemicunya. Kondisi ketika kehilangan gerak disebabkan oleh beberapa faktor seperti robekan rotator cuff, kalsifikasi tendinitis, artritis glenohumeral atau acromioclavicular, dan radikulopati serviks, dan bukan akibat restriksi kapsuler terisolasi, dapat diklasifikasikan sebagai Capsulitis Perekat sekunder (AC).

Terapi untuk kondisi ini harus mengatasi penyebab spesifik yang mendasarinya. Di sisi lain, idiopatik AC digunakan untuk kasus tanpa pemicu spesifik [14]. Perbedaan antara kelompok kontrol dan kelompok dengan kaku dan nyeri bahu yang diklasifikasikan lebih lanjut ditunjukkan oleh data pengukuran pada tabel 1. Dari data tersebut, dapat dilihat bahwa rata-rata IA dari semua kasus AC tampak lebih tinggi daripada kelompok kontrol.

Tabel 1 Hasil pengukuran Indeks Adhesi (IA)

\begin{tabular}{|l|c|c|}
\hline \multicolumn{1}{|c|}{ Grup } & Indeks Adhesi (IA) & Sudut ER maksimum $\left(^{\circ}\right)$ \\
\hline Kontrol & $0.37 \pm 0.198$ & $66.875 \pm 12.48$ \\
\hline AC idiopatik & $0.556 \pm 0.22$ & $39.17 \pm 15.39$ \\
\hline AC sekunder & $0.544 \pm 0.2176$ & 34.37515 .9 \\
\hline
\end{tabular}




\section{KESIMPULAN DAN SARAN}

Perangkat lunak untuk memvisualisasikan peta kecepatan 2 dimensi dari gerakan bahu telah diimplementasikan. Perekatan antara subscapularis dan otot deltoid dapat diukur dengan menggunakan perangkat lunak ini. Metode visualisasi gerakan yang digunakan adalah speckle tracking.

Percobaan untuk menguji perangkat lunak ini dilakukan pada subyek sehat dan pasien dengan keluhan nyeri dan kesulitan gerak bahu. Terlihat bahwa observasi pasien menunjukkan adanya perekatan pada jaringan subscapularis. Secara umum, pengukuran menunjukkan bahwa adhesi subscapularis berkorelasi dengan ROM.

Implementasi metode speckle tracking ultrasonik untuk menganalisis secara kuantitatif nyeri dan kaku bahu telah dijelaskan dalam makalah ini. Metode ini mampu mengukur adhesi subscapularis, dengan menganalisis citra bergerak ultrasonik dari gerakan bahu. Hubungan antara adhesi subscapularis dan ROM serta kaitannya dengan penyakit nyeri dan kaku bahu ditampilkan. Metode speckle tracking telah diterapkan untuk ortopedi dan pengukuran menunjukkan bahwa indeks perekatan menjelaskan asal mula keterbatasan gerak, yang diharapkan bisa menjadi pelengkap pada assesmen ROM secara fisik karena mengesampingkan rasa sakit yang menyebabkan keterbatasan gerak dalam pemeriksaan. Hasil penelitian ini menyempurnakan penelitian sebelumnya, dimana terjadinya adhesi dinilai secara kuantitatif, dan observasi dapat dilakukan ke banyak subjek [15]

Namun, metode ini memiliki keterbatasan di mana temuan ini tidak dapat memberikan klasifikasi yang lebih jauh tanpa melibatkan modalitas tambahan. Hal ini dapat dimaklumi karena IA tidak dimaksudkan un tuk menggantikan modalitas tambahan dalam mengidentifikasi sumber kaku dan nyeri bahu yang terkait seperti MRI untuk Rotator Cuff Tears (RCT).

\section{DAFTAR PUSTAKA}

[1] Walker-Bone, K., Palmer, K. P., Reading, I., Coggon, D., Cooper, C., 2004, Prevalence and Impact of Musculoskeletal Disorders of the Upper Limb in the General Population, Arthritis \& Rheumatism, No. 4, Vol. 51, 642-651, https://onlinelibrary.wiley.com/doi/epdf/10.1002/art. 20535.

[2] Mezian, K., Coffey, R., Chang, K.-V., 2021, Frozen Shoulder, StatPearls Publishing, Taiwan.

[3] Dias, R., Cutts, S., Massoud, S., 2005, Frozen shoulder, BMJ, Vol. 331, 1453-1456, https://www.bmj.com/content/331/7530/1453.

[4] Tandon, A., Dewan, S., Bhatt, S., Jain, A. K., Kumari, R., 2017, Sonography in diagnosis of adhesive capsulitis of the shoulder: a case-control study, J Ultrasound, Vol. 20, 227-236, https://link.springer.com/content/pdf/10.1007/s40477-017-0262-5.pdf.

[5] Hoskins, P. R., 1997, Peak velocity estimation in arterial stenosis models using colour vector Doppler, Ultrasound in Medicine \& Biology, No. 6, Vol. 23, 889-897, https://www.umbjournal.org/article/S0301-5629(97)00033-1/pdf.

[6] Trahey, G. E., Allison, J. W., Ramm, O. T. v., 1987, Angle independent ultrasonic detection of blood flow, IEEE Trans Biomed Eng, No. 12, Vol. 34, 965-967, https://ieeexplore.ieee.org/document/4122484.

[7] Jensen, J. A., 2001, A new estimator for vector velocity estimation, IEEE Trans Ultrason Ferroelectr Freq Control, No. 4, Vol. 48, 886-894, https://backend.orbit.dtu.dk/ws/files/4151546/jensen.pdf.

[8] Hirano, R., Kanzaki, M., Arakawa, M., Hermawan, N., Kobayashi, K., Saijo, Y., 2019, Biomechanics of $\mathrm{C} 2 \mathrm{C} 12$ Cells Observed with Cellular Resolution Scanning Acoustic Microscope Combined with Optical Microscope, Proceeding of 41st Annual International Conference of the IEEE Engineering in Medicine \& Biology Society (EMBC), Berlin, 23-27 July. 
[9] Horn, B. K., Schunck, B. G., 1981, Determining Optical Flow, Artificial Intelligence, Vol. 17, 185-203, https://www.sciencedirect.com/science/article/abs/pii/0004370281900242.

[10] Lucas, B. D., Kanade, T., 1981, An Iterative Image Registration Technique with an Application to Stereo Vision, Prodeeding of intl 7th Intl Joint Conf on Artificial Intelligence (IJCAI), Vancouver, 24-28 August.

[11] D'hooge, J., 2007, Principles and Different Techniques for Speckle Tracking, Marwick, T. H., Yu, C-M., Sun, J. P. (Ed.), Myocardial Imaging: Tissue Doppler and Speckle Tracking, Blackwell Publishing Ltd., Malden.

[12] Neviaser, A. S., Neviaser, R. J., 2011, Adhesive Capsulitis of the Shoulder, Journal of the American Academy of Orthopaedic Surgeons, Vol. 19, 536-542, https://pubmed.ncbi.nlm.nih.gov/21885699/.

[13] Hermawan, N., Fujiwara, M., Hagiwara, Y., Saijo, Y., 2020, Visualization of Shoulder Ligaments Motion by Ultrasound Speckle Tracking Method, Proceeding of 42nd Annual International Conference of the IEEE Engineering in Medicine \& Biology Society (EMBC), Virtual, 20-24 July.

[14] Rahayu, Y., Nurhadiyono, B., 2012, Implementasi Matriks pada Matematika Bisnis dan Ekonomi, Techno.COM, No. 2, Vol. 11, 72-81, http://publikasi.dinus.ac.id/index.php/ technoc/article/view/930/699.

[15] Wurdianarto, S. R., Novianto, S., Rosyidah, U., 2014, Perbandingan Euclidean Distance dengan Canberra Distance pada Face Recognition, Techno.COM, No. 1, Vol. 13, 31-37, http://publikasi.dinus.ac.id/index.php/technoc/article/view/539/315. 